\title{
MORPHOMETRICAL CATEGORIZATION OF PHYLLOBOTHRIUM DELPHINI (CESTOIDEA, TETRAPHYLLIDEA) CYSTS FROM FRASER'S DOLPHIN, LAGENODELPHIS HOSEI (CETACEA, DELPHINIDAE)
}

\author{
Gabriela Failla Siquier ${ }^{1, *}$ and Alfredo E. Le Bas ${ }^{2,3}$
}

\begin{abstract}
The larvae of phyllobothriid cestode worms found in marine mammals have been classified as either "delphinii group" or "grimaldii group". The first group has been divided into 11 morphotypes by previous studies. However, these categories are vague and often overlap, as they were described from different host species within a wide geographical range. The goal of this study is to simplify the categorization of larval shape and size based on samples obtained from a single host species. Eleven Fraser's dolphin Lagenodelphis hosei Fraser, 1956 stranded on the coast of Uruguay in November 2001 and subsequently died. From these animals, 190 cysts of Phyllobothrium delphini (Bosc, 1802) were obtained from the perigenital blubber of one female and one male. The prevalence of $P$. delphini was $18.18 \%$, density was 159.38 larvae/ $\mathrm{kg}$ of perigenital blubber, mean intensity was 95 and mean abundance was 17.27. The following measurements were taken: total length (BL), width and thickness of cysts, neck length (NL), scolex length, scolex width, external diameter of the suckers, and the ratio BL/ NL. In order to facilitate further identification of these phyllobothriid cysts, they were grouped into three categories according to shape and size: category " $\mathrm{A}$ " $(22.35 \%$, neck always straight); category "B" $(62.35 \%$, all with curved neck); category " $\mathrm{C}$ " (15.30\%, U-shaped or with projections from the wall of the cyst, also curved neck). These morphological differences could correlate to time spent in the host. One other larval form (Tetrabothrius sp.) was also found in the blubber of these dolphins.

Resumen - Las larvas de filobotridios en mamíferos marinos fueron clasificadas como "grupo delphinii" y "grupo grimaldii". En estudios previos el primer grupo fue dividido en 11 morfotipos. Sin embargo, estas categorías son vagas y a menudo se solapan, ya que fueron descritas a partir de diferentes especies de hospedadores provenientes de una amplia distribución geográfica. El objetivo de este estudio es simplificar la categorización de tamaños y formas larvarias a partir de una muestra obtenida de un único hospedador. Se estudiaron once ejemplares muertos de Lagenodelphis hosei Fraser 1956 varados en la costa de Uruguay en noviembre de 2001. Ciento noventa quistes de Phyllobothrium delphini (Bosc, 1802) fueron obtenidas de la grasa perigenital de una hembra y un macho. La prevalencia de P. delphini fue del $18.18 \%$, la densidad 159.38 larvas/kg de grasa perigenital, la intensidad media 95 y la abundancia media 17.27. Se tomaron las siguientes medidas: largo total (BL), ancho y grosor del quiste, largo del cuello (NL), largo del scolex, ancho del scolex, diámetro externo de las ventosas y el cociente BL/NL. Para facilitar futuras identificaciones, estas larvas filobotrídeas fueron agrupadas en tres categorías de acuerdo a su tamaño y forma: categoría " $\mathrm{A}$ " (22.35\%, cuello siempre recto); categoría "B" (62.35\%, todas con cuello curvado) y categoría "C" (15.30\%, cuello curvado, quistes en forma de U o con proyecciones de la pared). Estas diferencias morfológicas podrían correlacionarse con el tiempo de permanencia en el hospedador. Sólo una forma larvaria fue determinada como Tetrabothrius sp., también encontrada en el panículo graso de estos delfines.
\end{abstract}

Key words: Lagenodelphis hosei, Phyllobothriidae, Phyllobothrium delphini, stranding, Uruguay.

\section{Introduction}

Two types of phyllobothriid cysts are recognized in marine mammals: Phyllobothrium delphini (Bosc, 1802), parasitizing the blubber coat, and Monorygma grimaldii (Monier, 1809), usually present in coelomic mesenteries. Baer (1932) named them the "delphinii group" and "grimaldii group" respectively.

The presence of the larval cestode Phyllobothrium delphini, has been reported for many cetacean species (Delyamure, 1955; Testa and Dailey, 1977; Dailey and Walker, 1978; Dailey, 1985; Abollo et al., 1998; Gibson et al., 1998). This parasite is commonly found within the blubber, typically concentrated in the perigenital region. Adult worms are found in the spiral valves of elasmobranch and holocephalan fishes, which ingest infected flesh either by predation or by scavenging (Euzet, 1994; Walker, 2001; Raga et al., 2002). The life cycle of this parasite is not clear and little is known about the biology of these larval forms.
Dailey and Walker (1978) found larval P. delphini to be the most common parasite in the blubber of 56 cetaceans (representing 4 species) stranded along the coast of South California, USA. Geraci et al. (1976) reported up to 570 larvae per host in the Atlantic white-sided dolphin, Lagenorhynchus acutus, from the western north Atlantic. Larvae of $P$. delphini have also been cited for Fraser's dolphin, Lagenodelphis hosei Fraser, 1956 (Tobayama et al., 1973; Testa and Dailey, 1977; McColl and Obendorf, 1982; van Bree et al., 1986; Abollo et al., 1998; Mignucci-Giannoni et al., 1999; Walker, 2001; Moreno et al., 2003).

Larval forms of the "delphinii group" exhibit great diversity in shape: Guiart (1935) described four cyst morphotypes, Delyamure (1955) documented two more and Testa and Dailey (1977) added another five to give the current total of 11. Unfortunately, previous descriptions lack clear differences between similar forms making the classification of morphotypes difficult. In addition, the definition of individual morphotypes is vague and does not contribute to the identification of phyllobothriid larvae. The size and

\footnotetext{
${ }^{1}$ Universidad de la República, Facultad de Ciencias, Departamento de Biología Animal, Sección Zoología Invertebrados. Iguá 4225. Montevideo, 11400. Uruguay. ${ }^{2}$ Universidad de la República, Facultad de Ciencias, Departamento de Biología Animal, Sección Fisiología y Nutrición. Iguá 4225. Montevideo, 11400. Uruguay. ${ }^{3}$ Protección de Fauna Marina (PROFAUMA). Montevideo, Uruguay.

*Corresponding author: gfailla@fcien.edu.uy. Phone: + 5982525 8619. Fax: + 59825258617
} 
shape of cestode larvae, including those of the Tetraphillidea, are extremely variable and depend on many factors, especially the age of larvae. This raises the question of the usefulness of previously described morphotypes and supports the need for a simpler categorization until a conclusive systematic determination can be made.

The present study was conducted to describe and characterize the $P$. delphini larvae recovered from Fraser's dolphins, based on their morphological variation within a single host. Consequently, a simple classification into three groups is presented. This is the first record of $P$. delphini parasitizing L. hosei for Uruguayan waters. In addition, an "atypical" morphology of one cyst is discussed.

\section{Material and Methods}

In November 2001, approximately 60 Fraser's dolphins were observed alive at the mouth of Santa Lucía river (34 $47^{\circ}$ S; 56 $21^{\prime} \mathrm{W}$, Uruguay). Approximately 35-40 dolphins were conducted to open waters and saved, but at least 21 individuals perished. Eleven dead specimens were recorded as ZVCM2133 to ZVCM2143 and were sampled for parasites within a day of death. From each individual, body measurements, sex and color pattern were recorded. A field necropsy was carried out for sampled animals to determine cause of death. Skulls were deposited in the Mammalian Collection of the Vertebrate Zoology Section and parasitological samples entered the Helminthological Collection of Invertebrate Zoology Section as BP/9004, Faculty of Sciences, Montevideo, Uruguay.

Whole skin surrounding the genital slit and anus was removed up to a distance of $30 \mathrm{~cm}$ for each animal, weighed in situ and fixed in $10 \%$ isotonic formalin solution. Two days later, samples were serially sectioned for cyst identification. Cysts of $P$. delphini were obtained from the perigenital blubber of one female (ZVCM2139) and one male (ZVCM2142). All larvae were removed, dehydrated and cleared in beechwood creosote for morphometrical study and a small sample $(\mathrm{N}=8)$ was used to perform SEM studies. They were critically point dried and coated with a Coating Denton Vacuum apparatus for $60 \mathrm{~s}$ at $40 \mathrm{~mA}$. Images were obtained from a JEOL JSM-5900LV electron microscope. Measurements were made by ocular micrometer using a Nikon SMZ-10 Axioskope microscope equipped with a drawing tube as follows:- BL: bladder length; BW: bladder width and BT: bladder thickness. Length and width of neck (NL, NW) and scolex (SL, SW) and outer diameter of accessory bothridial suckers (BS) (Fig.1). In order to characterize the shape of cysts, BL/NL ratio was used. Several scolices were stained with acetic carmin and mounted in Canada Balsam.

The total number of recovered cysts was 190. The criteria adopted to consider an entire cyst was the presence of a complete scolex (although the bladder cyst could be partially missing). One hundred and fourteen cysts were used for external and bothridial sucker measurements, twenty of which were used to measure the fifth apical sucker on the myzorhynchus. Eighty five cysts were used to estimate the three categories proposed. Images were obtained by an Olympus BX40 microscope with an adapted digital camera (50x). Standard parasitological parameters were used according to Bush et al. (1997). All parasitological measurements in $P$. delphini are expressed in $\mathrm{mm}$. Normality of errors of the transformed data set was determined by the Kolmogorov-Smirnov test at $\mathrm{p} \geq 0.05$ in order to perform descriptive statistics (Sokal and Rohlf, 1995). Statistical analysis were performed using Statistica 6.0 software.

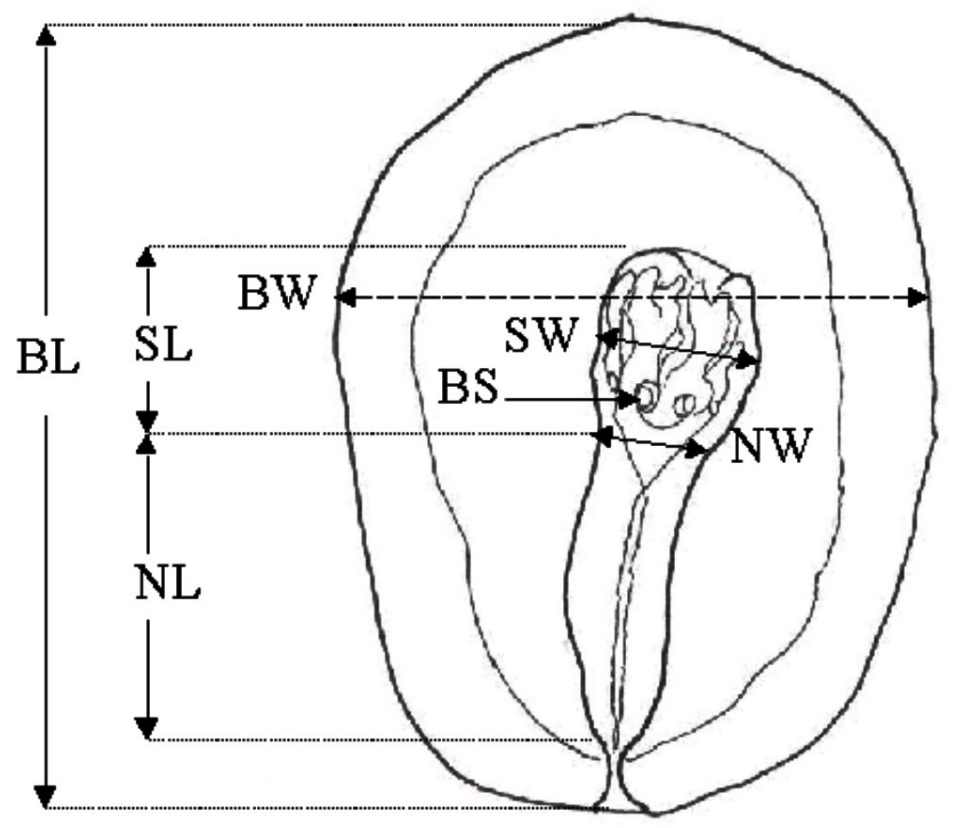

Figure 1. Schematic Phyllobothrium delphini cyst and its measurements: (BL) bladder length, (BW) bladder width, (NL) length of neck, (NW) width of neck, (SL) scolex length, (SW) scolex width, (BS) outer diameter of bothridial suckers. 


\section{Results}

One hundred and ninety cysts were recovered from two individuals ZVCM2142 $0^{\circ}(\mathrm{N}=117)$ and ZVCM2139 우 $(\mathrm{N}=73)$. Ten to 15 hours after host death, larvae were alive and easily separated themselves from host capsules. Microscopic examination of the scolex revealed 4 sessile auricular bothridia with smooth and folded edges, often loculated with adjacent edges touching (Fig.2c). One accessory sucker in each bothridium was observed (Fig.2a,c,e) and the myzorhynchus possessed an apical $5^{\text {th }}$ sucker (Fig.2b,d,e). Overall cyst prevalence was 18.18\% $(\mathrm{N}=190)$, density was 159.38 larvae per $\mathrm{kg}$ of blubber, mean intensity (total number of cysts/total number of infected hosts) was 95 and mean abundance (total number of cysts/ total number of sampled hosts) was 17.27.

Larvae were measured as follows:- neck length: NL, neck width: NW, scolex length: SL, scolex width: SW, bothridial suckers: BS, $5^{\text {th }}$ apical sucker length: ASL, and width:
ASW. As the data fit the normal distribution (Kolmogorov-Smirnov $\mathrm{d}=0.10449, \mathrm{p}>0.05)$, basic descriptive statistics were calculated: mean values on the 114 cysts measured for size and the 20 measured for $5^{\text {th }}$ apical sucker are shown in Table 1.

According to shape and size, bladder worms were grouped into 3 categories ( $N=85$, Table 2$)$. For category " $A$ " (22.35\%), neck always straight, BL ranging from 2.10 to $4.10 \mathrm{~mm}$ (Fig.3b,c). In category "B" (62.35\%), all with curved neck, BL ranging from 4.10 to $7.14 \mathrm{~mm}$ (Fig.3a,d,e). Category " $\mathrm{C}^{\prime}$ $(15.30 \%)$, U-shaped (Fig.4a,b) or with projections from the wall of the cyst (Fig.4c,d), also curved neck, usually $\mathrm{BL}>7.14 \mathrm{~mm}$. There was a tendency for the ratio BL/NL to be $>1$ and $<1$ in categories $\mathrm{A}$ and $\mathrm{C}$ respectively, but in category B it could give either of both results.

We also found one cyst with an external morphology similar to all others except the scolex morphology consisted of 4 muscular round and smooth bothridia, without an accessory apical sucker. This specimens'

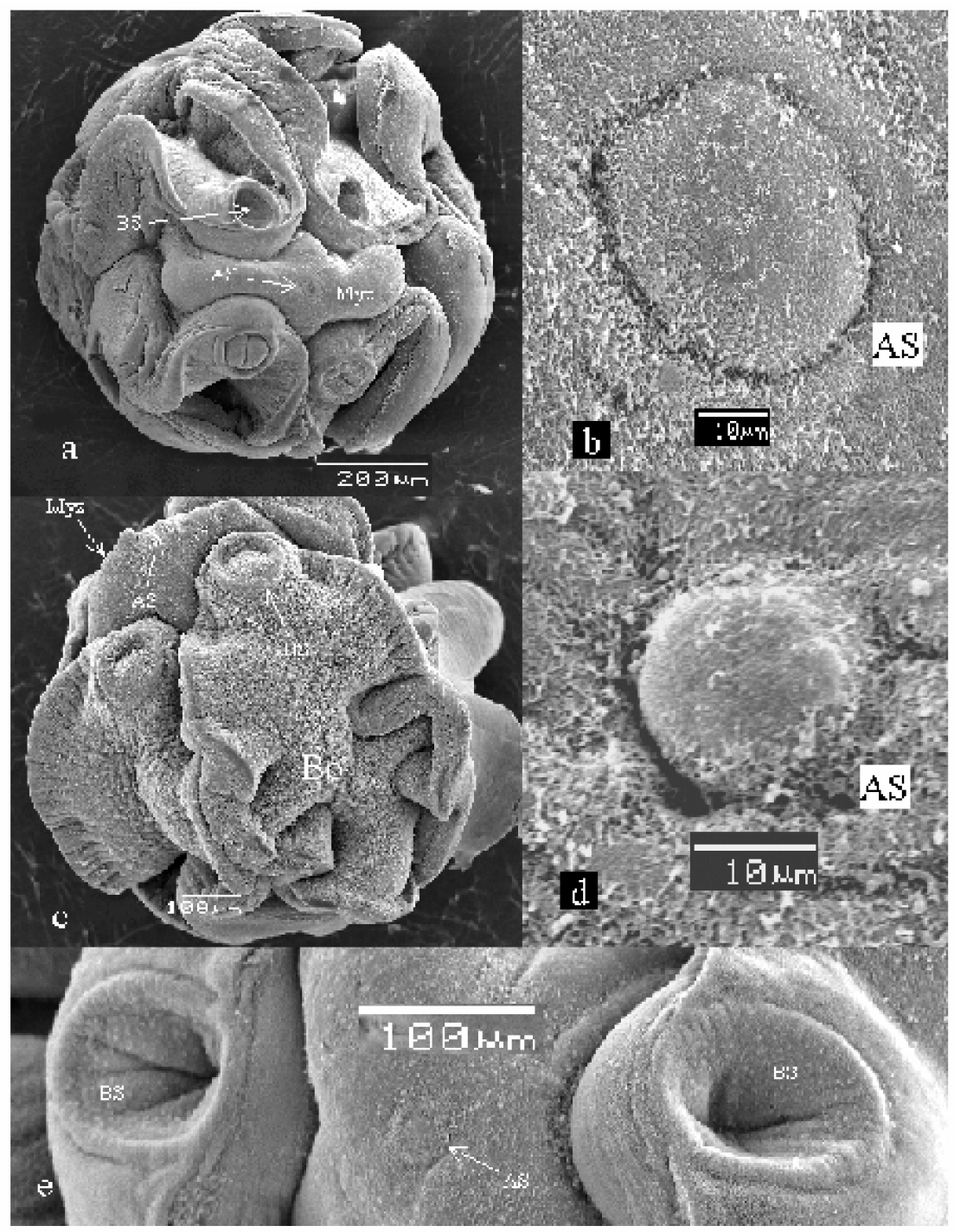

Figure 2. Scanning electron micrographs of the scolex of Phyllobothrium delphini (cyst removed) taken from five different scolices: (a) scolex, front view showing 4 bothridial suckers and one $5^{\text {th }}$ apical sucker; (b) $5^{\text {th }}$ apical sucker; (c) scolex, lateral view; (d) $5^{\text {th }}$ apical sucker; (e) apical and bothridial suckers; (AS) apical fifth sucker, (Bo) bothridium, (BS) bothridial sucker, (Myz) myzorhynchus. 
measurements were BL:3.57; WL:2.66; BL/NL:1.88; NL:1.89; NW:0.63 and SL:0.49, and was determined as Tetrabothrius sp.

The stranded dolphins were identified as L. hosei based on their color pattern and external morphology. No apparent pathologies were found during the inspection of the carcasses, therefore the causes of this stranding event remain unknown.

\section{Discussion}

The great scattering of our data suggests the existence of high morphological and size variability in larval development. Baer's (1932) groups "delphinii" and "grimaldii" are morphologically and spatially separated so no overlapping occurs, although they may be found in the same or different hosts. All larvae considered for this study were of the "delphinii group".

Table 1. Mean values $(\mathrm{mm})$ of the $5^{\text {th }}$ apical sucker and cysts of Phyllobothrium delphini.

\begin{tabular}{lcccccc}
\hline \hline & BL & BT & BW & BS & ASL & ASW \\
\hline \hline Mean & 5.25 & 3.68 & 3.07 & 0.150 & 0.073 & 0.067 \\
Standard Error & 0.12 & 0.09 & 0.07 & 0.002 & 0.001 & 0.002 \\
Median & 5.50 & 4.00 & 3.15 & 0.150 & 0.075 & 0.075 \\
Mode & 6.00 & 4.00 & 3.50 & 0.150 & 0.075 & 0.075 \\
Standard deviation & 1.25 & 0.98 & 0.81 & 0.019 & 0.004 & 0.010 \\
Variance & 15.50 & 9.57 & 6.50 & 0.015 & 0.000 & 0.004 \\
Range & 5.80 & 4.30 & 4.10 & 0.075 & 0.012 & 0.025 \\
Minimum & 2.50 & 1.20 & 1.20 & 0.100 & 0.062 & 0.050 \\
Maximum & 8.30 & 5.50 & 5.30 & 0.175 & 0.075 & 0.075 \\
$\mathrm{~N}$ & 114 & 114 & 114 & 114 & 20 & 20 \\
\hline \hline
\end{tabular}

(ASL) apical sucker length, (ASW) apical sucker width, (BL) bladder length, (BS) outer diameter of bothridial suckers, (BT) bladder thickness, (BW) bladder width.

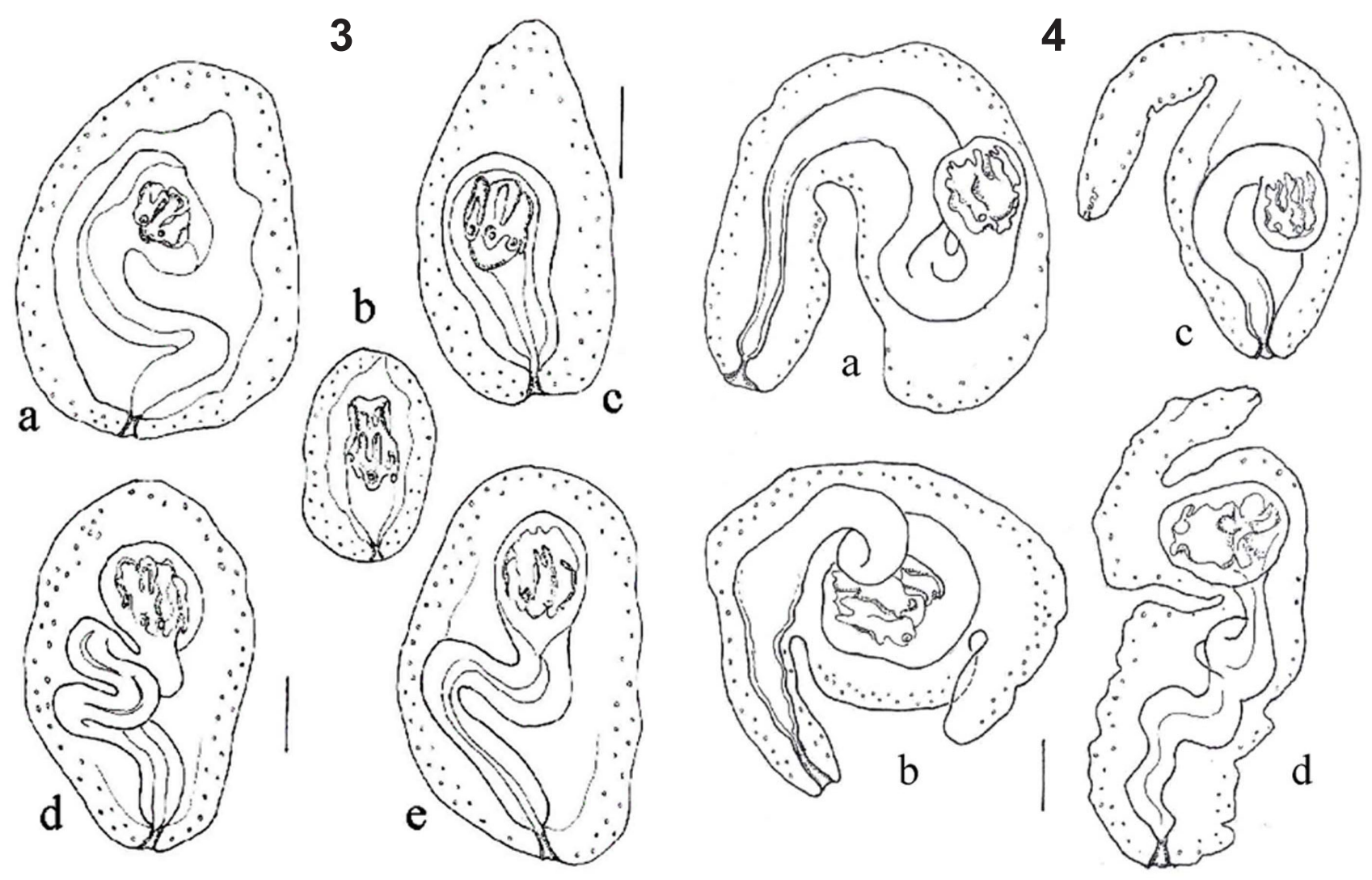

Figure 3. Phyllobothrium delphini morphotypes. According to the proposed classification, $a, d, e=$ category " $B$ "; $b, c=$ category " $A$ ". Bar=1mm (a,b,d,e); $0.5 \mathrm{~mm}$ (c). Figure 4. Category “C” cysts of Phyllobothrium delphini: $(\mathrm{a}, \mathrm{b})$ U-shaped cysts; $(\mathrm{c}, \mathrm{d})$ cysts with projections from the wall of the cyst. Bar=1mm. 
Table 2. Mean values (mm) of the morphometric measurements for the 3 proposed categories in Phyllobothrium delphini cysts.

\begin{tabular}{|c|c|c|c|c|c|}
\hline & $\mathrm{BL}$ & NL & NW & SL & SW \\
\hline \multicolumn{6}{|c|}{ Category A } \\
\hline Mean & 3.11 & 1.12 & 0.59 & 1.20 & 1.07 \\
\hline Standard Error & 0.12 & 0.28 & 0.06 & 0.06 & 0.06 \\
\hline Median & 3.01 & 0.77 & 0.63 & 1.26 & 1.05 \\
\hline Mode & 4.06 & 0.35 & 0.70 & 0.84 & 1.05 \\
\hline Standard deviation & 0.50 & 1.23 & 0.28 & 0.24 & 0.27 \\
\hline Variance & 0.25 & 1.52 & 0.08 & 0.06 & 0.07 \\
\hline Range & 1.61 & 5.24 & 1.04 & 0.84 & 0.98 \\
\hline Minimun & 2.45 & 0.01 & 0.01 & 0.84 & 0.70 \\
\hline Maximun & 4.06 & 5.25 & 1.05 & 1.68 & 1.68 \\
\hline $\mathrm{N}$ & 19 & 19 & 19 & 19 & 19 \\
\hline \multicolumn{6}{|c|}{ Category B } \\
\hline Mean & 5.74 & 5.08 & 0.86 & 1.66 & 1.51 \\
\hline Standard Error & 0.10 & 0.23 & 0.02 & 0.04 & 0.04 \\
\hline Median & 5.81 & 5.25 & 0.84 & 1.61 & 1.54 \\
\hline Mode & 5.95 & 5.74 & 0.84 & 1.54 & 1.75 \\
\hline Standard deviation & 0.72 & 1.64 & 0.18 & 0.30 & 0.28 \\
\hline Variance & 0.52 & 2.70 & 0.03 & 0.09 & 0.08 \\
\hline Range & 2.94 & 7.63 & 0.91 & 1.33 & 1.40 \\
\hline Minimun & 4.20 & 1.12 & 0.49 & 0.91 & 0.70 \\
\hline Maximun & 7.14 & 8.75 & 1.40 & 2.24 & 2.10 \\
\hline $\mathrm{N}$ & 53 & 53 & 53 & 53 & 53 \\
\hline \multicolumn{6}{|c|}{ Category C } \\
\hline Mean & 9.89 & 7.90 & 0.83 & 1.56 & 1.52 \\
\hline Standard Error & 0.47 & 0.51 & 0.05 & 0.08 & 0.06 \\
\hline Median & 10.15 & 8.12 & 0.77 & 1.61 & 1.47 \\
\hline Mode & 12.25 & 8.75 & 0.77 & 1.61 & 1.54 \\
\hline Standard deviation & 1.68 & 1.84 & 0.17 & 0.30 & 0.21 \\
\hline Variance & 2.83 & 3.37 & 0.03 & 0.09 & 0.04 \\
\hline Range & 4.55 & 6.30 & 0.63 & 1.05 & 0.77 \\
\hline Minimun & 7.70 & 4.55 & 0.63 & 1.05 & 1.26 \\
\hline Maximun & 12.25 & 10.85 & 1.26 & 2.10 & 2.03 \\
\hline $\mathrm{N}$ & 13 & 13 & 13 & 13 & 13 \\
\hline
\end{tabular}

(BL) bladder length, (NL) neck length, (NW) neck width, (SL) scolex length, (SW) scolex width.

Our larvae categories are difficult to compare with those previously described, due to overlapping measurements. It is not possible to compare our categories with those of Testa and Dailey (1977), which are the result of a pool of larvae ( $\mathrm{N}=81)$ extracted from 12 different cetacean hosts (including only 7 bladder worms from $L$. hosei) within a wide geographical range. Therefore, following the assumption that our larvae correspond to $P$. delphini, we attribute the differences in size and shape to adaptation to hosts tissues and size, geographical variation, and the larval stage of development in the host. Geographical differences have been observed previously for P. delphini in Dall's porpoise (Walker, 2001).

The fifth apical sucker on the myzorhynchus was difficult to observe because in some specimens it was extremely reduced. This apical sucker could not be seen in the stained scolices under the optical microscope and the structure observed under the electron microscope cast doubt on its use as a fixation organ, at least at this level of development. Larval permanence within the host could explain size and shape diversity. A possible consequence of this process could be the enlargement or folding of some cysts (category " $\mathrm{C}$ " cysts: $15.30 \%$ ). On the other hand, cysts could be affected by density of parasites, host blubber characteristics and geographical location of both intermediate(s) and definitive hosts. Geographical location is not a factor in our samples, which come from the same species, social group and locality. To assess the meaning of presented categories a temporal hypothesis can be suggested: category " $C$ " cysts could be those inhabiting host tissues for longer periods, while category " $\mathrm{A}$ " $(22.35 \%)$ could represent more recent infections. Category "B" $(62.35 \%)$ cysts may be taken as intermediate, involving the main stock of oval-like, curved neck cysts. Consequently, 
the morphological differences in the 3 categories of cysts could correlate to time spent in the host. The ratio BL/NL was not useful for the three categorizations proposed.

One larval form had similar external characteristics to the other bladder worms but differed internally. According to Hoberg (1994) it was determined to be Tetrabothrius sp. Rudolphi, 1819. This parasite has been found in L. hosei by Tobayama et al. (1973) in the stomach, and Mignucci-Giannoni et al. (1999) in the blubber. Due to the fact that they could share the same site of infection and external similarities these larvae could be easily confused with $P$. delphini.

We emphasize the monospecific character of this study, relating to the cetacean host $L$. hosei. Further studies on other hosts will be needed to extrapolate the categories proposed. As previously mentioned, Fraser's dolphins could act as intermediate or accidental hosts, and definitive host infection could occur by predation on cetaceans. According to Walker (2001) the concentration of $P$. delphini cysts in the posteriorabdominal blubber layer of the hosts could be advantageous for the successful transmission of this larval cestode. The presence of bite marks probably caused by the cookie-cutter shark Isistius brasiliensis on stranded specimens of L. hosei supports this hypothesis (J. Lailson-Brito Jr, UFRJ, Rio de Janeiro, Brazil, pers. comm.; Perrin et al., 1993).

\section{Acknowledgements}

We are indebted to Lic. Alberto Ponce de León from the Departamento de Mamíferos Marinos of the Dirección Nacional de Recursos Acuáticos (DINARA) for institutional support, and to the Armada Nacional for providing logistical support during the rescue of living animals. This work was possible because of the effort of all the volunteers from the NGO PROFAUMA (Protección de Fauna Marina). The authors are especially grateful to Dr. Murray Dailey, for facilitating specific bibliography and for his critical revision of this manuscript. We also want to thank Dr. William Walker and the cetologist Ricardo Praderi for bibliographic support, Dr. Thomas Scholtz for his useful criticism and to Prof. Rodrigo Ponce de León for his comments and support. We thank the diligence of Gabriel Santoro, Matías Arim and the Servicio de Microscopía Electrónica de Barrido of the Facultad de Ciencias. We express our appreciation to Dr. J.A. Raga, Dr. J. Reyes and Oliver Boisseau for their constructive criticism of the manuscript as reviewers.

\section{References}

Abollo, E., Lopez, A., Gestal, C., Benavente, P. and Pascual, S. (1998) Macroparasites in cetaceans stranded on the northwestern Spanish Atlantic coast. Diseases of Aquatic Organisms 32: 227-231.

Baer, J.G. (1932) [Contribution to the study of cestodes of cetaceans] Contribution à l'étude des Cestodes de Cétacés. Revue Suisse de Zoologie 39: 195-228.

Bush, A.O., Lafferty, K.D., Lotz, J.M., Shostak, A.W. (1997) Parasitology meets ecology on its own terms: Margolis et al. revisited. Journal of Parasitology 83:575-583.

Dailey, M.D. (1985) Diseases of Mammalia: Cetacea. Pages 805847 in Kinne, O. (Ed.) Diseases of marine animals. Vol. IV, 2. Biologische Anstalt Helgoland., Hamburg.
Dailey, M.D. and Walker, W.A. (1978) Parasitism as a factor (?) in single strandings of southern California cetaceans. Journal of Parasitology 64: 593-596.

Delyamure, S.L. (1955) Helminthofauna of Marine Mammals (Ecology and Phylogeny). Izda'telstvo Akademii Nauk SSSR, Moscow, Russia. Translated from Russian by the Israel Program for Scientific Translation, Jerusalem, 1968.

Euzet, L. (1994) Order Tetraphyllidea Carus, 1863. Pages 149-194 in Khalil, L. F., Jones, A. and Bray, R. A. (Eds) Keys to the Cestode Parasites of Vertebrates. CAB International Pub., Wallingford.

Geraci, J.R., Testaverde, S.A., St.Aubin, D.J. and Loop, T.H. (1976) A mass stranding of the Atlantic white-sided dolphin, Lagenorhynchus acutus: a study into pathobiology and life history. US Marine Mammal Commission, Washington.

Gibson, D.I., Harris, E.A., Bray, R.A., Jepson, P.D., Kuiken, T., Baker, J.R. and Simpson, V.R. (1998) A survey of the helminth parasites of cetaceans stranded on the coast of England and Wales during the period 1990-1994. Journal of Zoology 244: 563-574.

Guiart, J. (1935) [Parasitic cestodes from the scientific cruises of S.A.S. the Prince Albert I (1886-1913)] Cestodes parasites provenant des campagnes scientifiques de S.A.S. le Prince Albert Ier (1886-1913). Résultats des Campagnes Scientifiques accompliés par le Prince Albert 1, Monaco 1(91): 1-100.

Hoberg, E.P. (1994) Order Tetrabothriidea Baer, 1954. Pages 295-304 in Khalil, L.F., Jones, A. and Bray, R.A. (Eds) Keys to the Cestode Parasites of Vertebrates. CAB. International Pub., Wallingford.

McColl, K.A. and Obendorf, D.I. (1982) Helminth parasites and associated pathology in stranded Fraser's dolphins, Lagenodelphis hosei (Fraser, 1956). Aquatic Mammals 9(2): 30-34.

Mignucci-Giannoni, A.A., Montoya-Ospina, R.A., Perez-Zayas, J.J., Rodriguez-Lopez, M.A. and Williams, J.R.E.H. (1999) New records of Fraser's dolphins (Lagenodelphis hosei), for the Caribbean. Aquatic Mammals 25: 15-19.

Moreno, I.B., Danilewicz, D., Borges-Martins, M., Ott, P.H., Caon, G. and Oliveira, L.R. (2003) Fraser's dolphin (Lagenodelphis hosei Fraser, 1956) in southern Brazil. The Latin American Journal of Aquatic Mammals 2(1): 39-46.

Perrin, W.F., Leatherwood, S. and Collet, A. (1993) Fraser's dolphin Lagenodelphis hosei Fraser, 1956. Pages 225-240 in Ridgway, S.H. and Harrison, R. (Eds) Handbook of marine mammals. Vol 5. Academic Press, London.

Raga, J.A., Fernandez, M., Balbuena, J.A. and Aznar, F.J. (2002) Parasites. Pages 867-876 in Perrin, W.F., Wursig, B. and Thewissen, H.G.M. (Eds) Encyclopedia of marine mammals, Academic Press, San Diego.

Sokal, R.R. and Rohlf, F.J. (1995) Biometry. Third Edition. Freeman, New York.

Testa, J. and Dailey, M.D. (1977) Five new morphotypes of Phyllobothrium delphini (Cestoda: Tetraphyllidea), their relationship to existing morphotypes, and their zoogeography. Bulletin of the Southern California Academy of Sciences 76: 99-110.

Tobayama, T., Nishiwaki, M. and Yang, H.C. (1973) Records of the Fraser's dolphin (Lagenodelphis hosei) in the western north Pacific. Scientific Reports of the Whale Research Institute 25: 251-263.

Van Bree, P.J.H., Collet, A., Desportes, G., Hussenot, E. and Raga, J.A. (1986) [The Fraser's dolphin, Lagenodelphis hosei (Cetacea, Odontoceti), new species for the fauna of Europe] Le dauphin de Fraser, Lagenodelphis hosei (Cetacea, Odontoceti), espèce nouvelle pour la faune d'Europe. Mammalia 50: 57-86.

Walker, W.A. (2001) Geographical variation of the parasite, Phyllobothrium delphini (Cestoda), in Dall's porpoise, Phocoenoides dalli, in the Northern North Pacific, Bering Sea, and Sea of Okhotsk. Marine Mammal Science 17: 264-275.

Received 7 August 2003. Accepted 22 October 2003. 